\title{
Internetske izvedbene umjetnosti u doba pandemije: nužno zlo ili nova kulturna praksa?
}

\author{
Lana Domšić \\ Veleučilište Baltazar Zaprešić, Hrvatska \\ e-mail: ldomsic@bak.hr
}

\author{
Barbara Franić \\ Veleučilište Baltazar Zaprešić, Hrvatska \\ e-mail: bfranic@bak.hr
}

\section{Lucija Marjanović \\ Veleučilište Baltazar Zaprešić, Hrvatska \\ e-mail: marjanoviclucija3@gmail.com}

SAŽETAK Aktualna kriza uzrokovana virusom SARS-CoV-2 te posljedične mjere ograničavanja okupljanja, odgađanja javnih nastupa te zatvaranje kulturnih institucija snažno su pogodili sektor izvedbenih umjetnosti. Koncerti, kazalište i ples podrazumijevaju okupljanje velikog broja ljudi, tj. mogućnost kolektivnog uživanja u umjetničkim djelima. Ograničenja koja i dalje traju dovela su stoga do velikih ekonomskih gubitaka, zatvaranja radnih mjesta i ugrožavanja egzistencije nezavisnih umjetnika.

Istovremeno, digitalni mediji omogućili su prikazivanje brojnih kulturnih sadržaja putem interneta, te su se pojavili različiti nekonvencionalni načini izvedbi plesnih i kazališnih predstava, virtualni koncerti i posebna uprizorenja glazbenih događanja. Mrežna kulturna ponuda u početku je bila besplatna, a s vremenom se uvode i modeli naplaćivanja internetskih izvedbi.

Cilj ovog rada bio je mapirati različite prakse virtualne distribucije izvedbenih umjetnosti u Hrvatskoj koje su se pojavile kao odgovor na krizu uzrokovanu bolešću COVID-19 te istražiti stavove korisnika o internetskom prikazivanju izvedbenih umjetnosti i njihovu spremnost na plaćanje takvih sadržaja. Provedeno istraživanja pokazalo je da su hrvatske kulturne institucije i nezavisni umjetnici vrlo brzo reagirali i odgovorili na pandemijsku krizu pružanjem raznolikog internetskog sadržaja. Prema rezultatima ankete, više od polovice ispitanih studenata konzumiralo je neke od tih sadržaja tijekom razdoblja pandemije, no velika većina internetske izvedbe smatra lošijom zamjenom za izvedbe uživo i ne iskazuje namjeru praćenja takvih sadržaja nakon završetka pandemije.

Ključne riječi: kulturni i kreativni sektor, izvedbene umjetnosti, internetske izvedbe, digitalna potrošnja, COVID-19, pandemija, istraživanje korisnika, spremnost za plaćanje. 


\section{Uvod}

Kriza uzrokovana pandemijom bolesti COVID-19 te posljedične mjere ograničavanja okupljanja, dugotrajnog odgađanja javnih nastupa i zatvaranja mjesta održavanja kulturnih događanja snažno su pogodili sektor izvedbenih umjetnosti. Glazba, kazalište, ples, performans, cirkus i ulična umjetnost podrazumijevaju okupljanje velikog broja ljudi, to jest mogućnost kolektivnog uživanja u umjetničkim djelima. Ograničenja, koja u trenutku pisanja ovog rada i dalje traju, dovela su stoga do potpunog zastoja kulturne i medijske produkcije, velikih ekonomskih gubitaka i zatvaranja radnih mjesta. Kazališta, koncertne dvorane i organizatori festivala pretrpjeli su ogromne novčane gubitke, a nezavisnim umjetnicima, koji su i u normalnim uvjetima često u neizvjesnoj poziciji, sada je ugrožena egzistencija, kako pokazuju brojne studije na globalnoj razini (OECD, 2020.; Polivtseva, 2020.; UNESCO, 2020.; Florida i Seman, 2020.) i u Hrvatskoj (Krolo i sur, 2020.; Primorac, 2021.). Ipak, kulturna potražnja u vrijeme karantena i samoizolacija pokazala je da je svakodnevicu bez nekog oblika umjetnosti nemoguće i zamisliti, a činjenica da su nam sada više nego ikad potrebni umjetnici koji bi svojim stvaralaštvom olakšali kriznu situaciju cijelu industriju kulturnog stvaralaštva stavlja u vrlo paradoksalnu situaciju. Pandemija je dodatno pojačala proturječja i dileme u kulturnom sektoru oko uloge tehnologije, društvene uloge kulture i održivosti trenutnih modela financiranja (Banks i O’Connor, 2020.). Pojačala se svjesnost o tome koliko je cijela industrija krhka, a prisiljavajući sektor na prilagodbu potrebama socijalnog distanciranja, prelazak na mrežne platforme, reorganizaciju rada i smanjivanje troškova na minimum, kriza će ubrzati digitalizaciju kulturnog sektora, preoblikovati modele financiranja, smanjiti ovisnost o fizičkom iskustvu i stvoriti zamah za kreativnost $\mathrm{i}$ inovativnost.

Digitalni mediji omogućili su prikazivanje brojnih kulturnih sadržaja tijekom razdoblja pandemije putem interneta. U okviru izvedbenih umjetnosti javili su se različiti nekonvencionalni i virtualni načini izvedbi plesnih i kazališnih predstava te glazbenih koncerata i događanja. Uključivali su, između ostalog, snimanje i prikazivanje uživo (engl. live recording and streaming), pokretanje novih ili korištenje postojećih mrežnih platformi i društvenih mreža za distribuciju snimljenih sadržaja, nekonvencionalne produkcije djela izvedbenih umjetnosti i različite druge alternativne načine ostajanja u kontaktu s publikom uz pomoć novih digitalnih tehnologija. Virtualna kulturna ponuda u početku je bila besplatna, a $s$ vremenom su se počeli uvoditi različiti modeli naplaćivanja internetskih izvedbi, koje je tek dio publike prihvatio (Moffat, 2020.). Razlozi tome mogu biti raznoliki, od smanjene kupovne moći građana do toga što, za mnoge, jedinstveno kolektivno iskustvo izvedbi uživo nije moguće usporediti s gledanjem snimljenih izvedbi. Također, problem predstavlja „kultura besplatnog na Internetu prema kojoj samo zato što je online, trebalo bi biti jeftinije, idealno ne koštati ništa. Vidimo to u određivanju cijene bilo kojeg kreativnog proizvoda distribuiranog ili konzumiranog preko interneta." (Warren, 2020.) 
Cilj ovog rada istražiti je različite alternativne načine ostajanja u kontaktu s publikom uz pomoć novih digitalnih tehnologija koje su se pojavile kao odgovor na krizu uzrokovanu pandemijom bolesti COVID-19 te stav publike prema takvim praksama. U prvom dijelu rada opisat će se do sada provedena istraživanja na tu temu. Nakon toga prikazani su rezultati mapiranja praksi alternativne i virtualne distribucije izvedbenih umjetnosti u Hrvatskoj u razdoblju od travnja 2020. godine do travnja 2021. godine. Također, metodom ankete istraženi su stavovi i percepcije studenata o mrežnoj distribuciji izvedbenih umjetnosti, uključujući njihovu spremnost na plaćanje takvih proizvoda i sadržaja, te su rezultati prikazani u završnom dijelu rada.

\section{Pregled dosadašnjih istraživanja}

U posljednjih godinu dana, koliko traje kriza uzrokovana novim koronavirusom, mnogi autori dotaknuli su se utjecaja pandemije na kulturnu industriju i kulturne aktivnosti općenito te izvedbene umjetnosti specifično, sagledavajući ju iz različitih perspektiva. Dosadašnja istraživanja možemo podijeliti u dvije skupine:

- istraživanja koja se bave utjecajem krize na korisnike kulturnih sadržaja

- istraživanja koja se bave utjecajem krize na rad kulturnih institucija, umjetnika i stručnjaka.

\subsection{Istraživanja koja se bave utjecajem krize na korisnike kulturnih sadržaja}

Kao što je već ranije u tekstu spomenuto, kulturne se djelatnosti već godinu dana nalaze u paradoksalnom položaju - kulturni sadržaj publici je trenutno potreban više nego ikad, a same kulturne institucije i samostalni umjetnici primorani su prekinuti $s$ radom (ili ga znatno promijeniti). Pozitivne učinke kulture i kulturnih djelatnosti na opće zdravlje, blagostanje i kvalitetu života već su davno dokazali brojni znanstvenici (Matarasso, 1997.; Merli, 2002.), stoga ne čudi pojačana potražnja za tim sadržajima tijekom razdoblja tjeskobe i izolacije uzrokovanih pandemijskom krizom. Ono što svakako igra ulogu u trenutnoj situaciji razvoj je tehnologije i važnost društvenih mreža. Budući da je većina svjetske populacije svakodnevno koristila svoje pametne telefone, tablete i laptope, to je svakako do neke mjere olakšalo prezentiranje izvedbenog sadržaja te umjetnicima dalo prostor za kreativnost i inovativnost kako bi što više održali odnos s vlastitom publikom. Publika igra veliku ulogu u izvedbenim umjetnostima jer daje svoj odgovor gledanom sadržaju, odnosno interpretira kontekst izvedbe i sam sadržaj izvođenog, nakon čega odgovor daje u obliku kritika, prijedloga, komentara ili jednostavno osjećaja zadovoljstva izvedbom. Setiawan i sur. ističu ulogu društvenih mreža tijekom trenutne pandemije kao bitnog posrednika između publike, odnosno konzumenata sadržaja i stvaratelja kulturnih sadržaja u vidu međusobne komunikacije. Osim što je kulturni sadržaj u virtualnom formatu dostupniji široj 
publici, komunikacija između konzumenata i kreatora sadržaja uvelike je olakšana. Budući da sve društvene mreže sadrže različite oblike interakcije, kao što su komentari i „lajkovi“, uključenost publike u kulturni sadržaj može se činiti puno neposrednija i direktnija. Komunikacijski proces između publike i kreatora u internetskim/ virtualnim izvedbenim umjetnostima može se izgraditi kroz značajke odgovora kao što su „sviđa mi se“ i komentara na društvenoj platformi YouTube. Može se tumačiti da angažman publike u uvažavanju rada djeluje realnije. Ako se predstava gleda uživo na sceni, nije sigurno da će publika moći izraziti zahvalnost za rad umjetnika (Setiawan i sur., 2020.).

Prva reakcija kulturnog sektora na krizu bila je učiniti sve napore kako bi se nastavilo financirati umjetnike i organizacije, a druga održati minimalan stupanj aktivnosti koristeći nove tehnologije. Negrier i Teillet (prema Radermecker, 2020.) govore o svojevrsnom „šoku inovativnosti“, koji se sastojao u očekivanjima od kulturnog sektora da odmah krenu s pružanjem novih, inovativnih i kreativnih odgovora na krizu. Osim direktnoj komunikaciji s korisnicima, nove tehnologije i društvene mreže otvorile su vrata i različitim novim načinima konzumiranja kulturnih sadržaja, što je dovelo do toga da je potražnja za njima prije i tokom krize ostala nepromijenjena, dapače, čak je i porasla. Rademecker (2020.) u svojem je radu fokus stavila upravo na potrebe potrošača kulturnih sadržaja i trenutnu krizu objasnila kao svojevrsnu priliku za promjenu poslovnog modela kulturnih institucija i za razvoj kulturnih djelatnosti uzimajući više u obzir potrebe korisnika: „[...] može se tvrditi kako je trenutačna kriza prilika za kulturne institucije i industrije da obnove svoje poslovne modele i potaknu strukturalne promjene. Iz te perspektive, kao egzogeni tretman svih kulturnih podsektora, pandemija COVID-19 može se promatrati kao dosad neviđena prigoda za inovacije i eksperimentiranja“" (Rademecker, 2020.:14.).

U svom radu navodi kako su financijska i logistička podrška ključne u oporavljanju kulturnih djelatnosti nakon krize, ali isto tako ističe veće pridavanje važnosti korisnicima tijekom tog procesa. Kako bi to bilo moguće, autorica je istaknula četiri potrebne aktivnosti: dobiti sustavnije i točnije podatke o obrascima kulturne potrošnje, bolje procijeniti hedonističku vrijednost potrošnje digitalne umjetnosti, ojačati angažman i lojalnost potrošača prema kulturnim ustanovama te promicati individualnu dobrobit kao ključnu korist od umjetnosti i kulture.

Uz entuzijastične poglede na sadašnji i budući razvoj distribucije izvedbenih umjetnosti preko ekrana, od kojih neki predviđaju i razvoj nove globalne publike (Lee i sur., 2000.), javljaju se i zabrinuti glasovi, koji upozoravaju da "trka da se život stavi online ostavlja mnoštvo ljudi iza sebe" (Warnecke, 2020.), poput onih koji nemaju pouzdan pristup internetskoj vezi: starije, siromašne, ruralne zajednice. Autorica također smatra da stavljanje izvedbenih umjetnosti na internet dugoročno šteti odnosu između publike i djela jer u njihovim očima umanjuje vrijeme, energiju, prostor i novac koji je potrebno uložiti u „prave“ fizičke produkcije. 


\subsection{Istraživanja koja se bave utjecajem krize na rad kulturnih institucija, umjetnika i stručnjaka}

$S$ druge strane, češći fokus u istraživanjima i člancima na temu kulturne industrije tijekom krize uzrokovane bolešću COVID-19 stanje je kulturnih institucija, umjetnika i stručnjaka, problemi s kojima su se susretali tijekom pandemijske godine te sve promjene koje su bili primorani uvesti. Trenutno je na internetskim platformama dostupno više besplatnog kulturnog sadržaja nego ikad prije, što povlači pitanja isplativosti poduzimanja takvih koraka te što to znači za budućnost kulturnih institucija. Zaključak koji su gotovo svi radovi napisani na tu temu iznijeli jest da je područje kulturne djelatnosti jedno od područja najpogođenijih krizom zbog nemogućnosti održavanja događaja, fizičkog distanciranja, zatvaranja kazališnih i koncertnih dvorana i ograničavanja broja sudionika na javnim okupljanjima (UNESCO, 2020.; Polivtseva, 2020.; Comunian i England, 2020., Dumcke, 2020.). Zaklada „Kultura nova“ provela je istraživanje, koje je obuhvatilo 74 nevladine organizacije, o utjecaju krize na područje kulture i umjetnosti u Republici Hrvatskoj. Prema rezultatima istraživanja, kriza je najviše utjecala na prihode koje organizacije ostvaruju iz nadnacionalnih fondova te na upravljanje prostorom i zapošljavanje, a čak 32,4\% ispitanika procijenilo je pad prihoda između 25 i 50\%. Međutim, jedna pozitivna strana prelaska u virtualni svijet ipak je prisutna, a to je povećanje broja posjeta internetskim stranicama i društvenim mrežama kulturnih institucija, što je potvrdilo 54,8\% ispitanika (Krolo i sur., 2020.)

Situacija je slična u većini europskih zemalja. Ukupno kulturno i kreativno gospodarstvo u Europi 2020. godine izgubilo je oko 31\% svojih prihoda, čime postaje jedno od krizom najpogođenijih područja u Europi, a najveće gubitke broje izvedbene umjetnosti i glazbena industrija (EY, 2021.) Mnogi umjetnici obeshrabreni su trenutnom situacijom, zbog čega nerijetko posao nastoje pronaći u drugim sektorima te umjetnost ostavljaju po strani. S druge strane, brojna su svjedočanstva o tome kako pojedinci i organizacije nastoje i dalje stvarati (Lee i sur., 2000), okrećući se internetu kao komunikacijskom sredstvu, što dio publike objeručke prihvaća, uglavnom očekujući besplatne sadržaje i bez razumijevanja da umjetnici od nečega trebaju i živjeti. Bonin-Rodriguez i Vakharia (2020.:5) u svom članku prenose riječi Scotta Blackshirea: „Socijalno distanciranje, trenutačno obilježje dobrog građanstva, traži od umjetnika da pomoću tehnologije dolaze do publike koja masovno zahtijeva svoju zabavu tijekom karantene (engl. quarantainment). Umjetnici odgovaraju na njihove zaglušujuće zahtjeve i rade - uglavnom besplatno - da bi predstavili zadivljujuće, duboke i urnebesne predstave koje odišu emocionalnom složenošću usprkos strogom internetskom okruženju - poput one gudačkog kvarteta Dafne koja se emitirala iz praznog Teatra Fenice u Veneciji; ili glumačka kratka forma, improvizirana izvedba / online rođendan; ili \#stayathome izdanje emisije Saturday Night Live. Bez obzira na pandemiju, takav besplatan rad nije održiv." 


\section{Metodologija}

Istraživačka pitanja s kojima se krenulo u ovo istraživanje bila su:

1. Na koji je način sektor izvedbenih umjetnosti u Hrvatskoj koristio informacijskokomunikacijsku tehnologiju tijekom pandemije koronavirusa kako bi nastavio aktivnosti, distribuirao sadržaje i ostao u kontaktu s publikom?

2. Kakve stavove publika ima o internetskim izvedbama scenskih nastupa te je li (i koliko je) spremna takve sadržaje platiti?

Prvi dio istraživanja odnosio se na mapiranje postojećih praksi internetskih nastupa od početka pandemije do razdoblja pisanja ovog rada, odnosno u godini dana od ožujka 2020. do ožujka 2021. godine. Pri tome se nastojalo otkriti koji oblici internetskog prikazivanja izvedbenih umjetnosti postoje, koje se tehnologije koriste i na kojim su internetskim platformama sadržaji plasirani te jesu li oni za korisnike bili besplatni ili su zahtijevali plaćanje.

Drugi dio istraživanja odnosio se na provođenje ankete kojom su ispitani stavovi i percepcije studenata o internetskim izvedbama kazališnih predstava i koncerata. Upitnik je sadržavao 25 pitanja podijeljena u tri grupe:

- pitanja koja se odnose na kulturne navike studenata prije i tijekom pandemije koronavirusa, općenito i specifično vezano uz konzumaciju sadržaja izvedbenih umjetnosti

- pitanja koja se odnose na stavove i percepcije studenata o internetskom prikazivanju izvedbenih umjetnosti, uključujući pitanja koja se odnose na procjenu spremnosti za plaćanje takvih sadržaja

- pitanja koja se odnose na sociodemografske karakteristike ispitanika (institucija, vrsta studija i način studiranja, rad uz studij, procjena mjesečnih primanja po članu kućanstva, dob i spol).

Podaci su prikupljeni pisanim internetskim upitnikom, a struktura uzorka prikazana je u tablici 1. Uzorak istraživanja bio je prigodni, a činili su ga studenti preddiplomskih i diplomskih studija Veleučilišta Baltazar Zaprešić i Ekonomskog fakulteta u Zagrebu. Upitnik je distribuiranim preko mailing lista, a ukupan je broj ispitanika 208. 
Tablica 1.

Uzorak prema instituciji studiranja, razini i načinu studiranja te spolu

\begin{tabular}{|l|l|c|c|}
\hline & & $\mathrm{N}$ & $\%$ \\
\hline UKUPNO ISPITANIKA & & $\mathbf{2 0 8}$ & $100 \%$ \\
\hline \multirow{2}{*}{ Visokoškolska institucija } & Veleučilište Baltazar Zaprešić & 164 & $80 \%$ \\
\cline { 2 - 4 } & Ekonomski fakultet u Zagrebu & 44 & $20 \%$ \\
\hline \multirow{2}{*}{ Razina studija } & Preddiplomski studij & 156 & $75 \%$ \\
\cline { 2 - 4 } & Diplomski studij & 52 & $25 \%$ \\
\hline \multirow{2}{*}{ Način studiranja } & Redoviti & 68 & $33 \%$ \\
\cline { 2 - 4 } & Izvanredni & 140 & $67 \%$ \\
\hline \multirow{3}{*}{ Spol } & Muški & 66 & $32 \%$ \\
\cline { 2 - 4 } & Ženski & 142 & $68 \%$ \\
\hline Rad uz studij & $\mathrm{Da}$ & 187 & $90 \%$ \\
\hline & $\mathrm{Ne}$ & 21 & $10 \%$ \\
\hline
\end{tabular}

\section{Rezultati mapiranja postojećih internetskih praksi}

U vremenskom periodu malo kraćem od godinu dana, točnije od sredine ožujka 2020. do sredine veljače 2021. godine, društvene mreže, mrežne stranice i ostale internetske platforme zamijenile su drvene pozornice te postale glavni čimbenik u očuvanju kulture i kulturnih aktivnosti tokom pandemije. Mnoge kulturne institucije, kao i samostalni umjetnici, pokušali su na najbolji način okrenuti trenutnu situaciju u svoju korist i iskoristiti sve što im društvene mreže, i ostale mrežne platforme općenito, nude. Kulturne aktivnosti i glazbeno scenski sadržaj prenosili su se u različitim oblicima, te prijenose možemo podijeliti u tri kategorije:

- prijenos kulturnog sadržaja uživo

- virtualno događanje

- $\quad$ snimka na zahtjev.

Sveukupan broj internetskih inicijativa u periodu od 11 mjeseci nešto je veći od 70, od čega se 20-ak inicijativa odnosi na kazališta koja su svoje kazališne predstave preselili na mrežne platforme; svako kazalište broji još nekolicinu vlastitih predstava koje su svoje mjesto pronašle na internetu.

Prijenos uživo uglavnom se odnosi na prijenos glazbenog sadržaja, što iz koncertnih dvorana što iz udobnosti vlastitih domova. Jedna od prvih inicijativa takvog tipa bio je projekt portala 24sata s naslovom \#zajedno24sata, koji je s radom počeo u ožujku 2020. godine i traje sve do danas. U sklopu inicijative, redakcija je portala u dogovoru s HNK-om u Zagrebu 18. ožujka 2020. godine krenula s objavljivanjem kazališnih predstava na internetskoj stranici, od kojih je prva Tko pjeva zlo ne misli. Iako je pro- 
jekt uglavnom fokusiran na prijenos snimki kazališnih predstava, njime je započet i val prijenosa koncerata uživo. 19. ožujka 2020. godine mnogi hrvatski glazbenici ujedinili su se i održali besplatan koncert za javnost, svatko iz udobnosti svoga doma putem YouTube kanala portala 24sata. Koncert broji preko 26000 pregleda na kanalu i još je uvijek dostupan javnosti. Nakon koncerta u organizaciji 24sata s prijenosom glazbenog sadržaja uživo krenuli su i brojni drugi glazbenici - što „intimno“ na vlastitim društvenim mrežama i kanalima što s malo većom organizacijom. Jedan od najuspješnijih koncerata koji se prenosio uživo bio je Remote Festival, održan u veljači 2021.godine. $U$ dva dana nastupali su brojni domaći glazbenici i grupe $s$ različitih lokacija, a gledatelji su koncerte mogli pratiti po cijenama od $50 \mathrm{kn}$ za jednu večer i 60 kn za obje večeri. Ono po čemu se festival ističe od ostalih internetskih koncerata jest trud uložen u produkciju koncerta takvog tipa, u kojoj je sudjelovao velik broj dizajnera rasvjete i videa.

Osim toga, prenosio se velik broj besplatnih koncerata, kao što su humanitarni koncert „Gustafi, Šajeta i MedVid za Petrinju“, novogodišnji doček uz Dinu Merlina, Božić s Ansamblom LADO, ciklus koncerata "Glazba može promijeniti svijet“ i obljetnički koncert Gudačkog kvarteta Sebastian. Uz Remote Festival, održalo se također nekoliko koncerata koji su se prenosili uživo, a za koje su se naplaćivale ulaznice. 14. veljače 2021. godine koncert za Valentinovo Josipe Lisac naplaćivao se između 80 i $120 \mathrm{kn}$ (ovisno o datumu kupovine karata), a koncert je pratilo oko 1000 gledatelja. Iz koncertne dvorane Lisinski također su se prenosili koncerti preko internetskih platformi uz kupnju ulaznica od $60 \mathrm{kn}$.

Virtualna događanja uglavnom su zamijenila razne festivale i okupljanja uživo. Događanja takvog tipa podrazumijevaju korištenje određene mrežne platforme za organizaciju neke aktivnosti koja ne podrazumijeva prijenos uživo. Održana virtualna događanja u periodu od ožujka 2020. godine do veljače 2021. godine uglavnom su festivali, koji su također nastojali iskoristiti trenutnu situaciju što je više i bolje moguće. Samo neki od virtualnih događanja su Dubrovnik Film Festival, Zagreb Film Festival i Human Rights Festival, koji su se održali na više-manje isti način. Filmovi festivala bili su dostupni gledateljima na mrežnim stranicama festivala, bez troškova ulaznica, te su se održavale i radionice i diskusije na temu određenih filmova. Virtualni oblik poprimila su i događanja nešto drugačijeg tipa kao što su revije i natjecanja, na kojima se sadržaj prenosio uživo, a glasovanje i ocjenjivanje sadržaja naknadno se provodilo također preko internetskih platformi. Jedan od događaja takvog tipa 53. je Susret zborova, održan putem interneta, na kojemu je sudjelovalo osam zborova sa sveukupno više od 200 pjevača. Natjecanje se održalo u obliku emisije sa snimkama izvedbi zborova, koje se emitiralo preko internetske stranice Hrvatskog sabora kulture, Facebooka te Youtube kanala, a stručno povjerenstvo sudjelovalo je u okruglom stolu sa sudionicima Susreta putem platforme Zoom. 
Snimke na zahtjev najbrojniji su oblik virtualnog prenošenja kulturnih aktivnosti. Sadržaj možemo podijeliti na snimke svirki i kratke videouratke koji su dostupni za naknadno gledanje, kao što su virtualna svirka Gorana Bare i Majki (uz kupnju „ulaznice" od $20 \mathrm{kn}$ ), film Antivirus Grupe modernog plesa Baletnog studija HNK Split i $8 a m$ - kratki film Aarona Koka, solista splitskog Baleta, te na snimke kazališnih predstava različitih hrvatskih kazališta. Više od dvadeset kazališta diljem Hrvatske pustilo je za javnost snimke svojih kazališnih predstava, plesnih izvedbi, opera itd. Među najuspješnijima i najrazvikanijima zasigurno je HNK u Zagrebu, koji je i započelo $s$ prikazivanjem predstava putem internetskih platformi na svojoj mrežnoj stranici sredinom ožujka 2020. godine predstavom Tko pjeva zlo ne misli. Snimke svojih kazališnih predstava objavili su i HNK Split, Teatar Kerekesh, Kazalište Kerempuh, Kazalište Komedija, Kazalište Gavella, ZKM i mnogi drugi. Sav kazališni sadržaj na zahtjev besplatan je za sve zainteresirane, a većina kazališta odredila je period u kojem će svaka predstava (odnosno svaka snimka predstave) biti dostupna gledateljima.

Među brojnim kulturnim sadržajem koji nam je bio ili još uvijek je ponuđen na internetskim platformama nalaze se određeni koji su osmišljeni kao novi načini prenošenja kulturnog sadržaja, a da nisu isključivo prijenos snimki na internetskim stranicama ili prijenos uživo.

Najkreativniji odgovor na prelazak na mrežne platforme zasigurno je imao kazališni i filmski redatelj Bobo Jelčić s predstavom Višnjik u Višnjiku. Taj autorski projekt redatelja predstava je koja nastaje i izvodi se u potpunosti u virtualnom prostoru kao odgovor na trenutnu situaciju u kojoj je onemogućen direktan kontakt glumaca $s$ publikom. Premijera predstave održala se 22. prosinca 2020. godine putem platforme Zoom, a sama predstava izvodi se u formi konferencijskog razgovora. Projekt je nastao iz potrebe da se istraže nove mogućnosti stvaranja predstava, koje se ne odnose samo na reprodukciju već snimljenih predstava, koje najčešće nisu ni snimane s namjerom da publici budu prikazane putem digitalnih medija. Posebnost je takvog izvođenja predstave publika koja je izloženija nego u klasičnom načinu izvođenja predstave, gotovo da je izjednačena s glumačkom postavom, odnosno likovima, čime se otvara mogućnost aktivnijeg participiranja gledatelja. Za gledanje predstave potrebna je ulaznica po cijeni od $40 \mathrm{kn}$, a predstava je još uvijek aktualna.

\section{Rezultati ankete}

Glavni cilj anketnog istraživanja bio je istražiti stavove i percepcije studenata o internetskom prikazivanju izvedbenih umjetnosti te njihovu spremnost za plaćanje takvih sadržaja. Prvim dijelom upitnika nastojalo se istražiti u kojoj su mjeri studenti konzumirali kulturne sadržaje prije i tijekom pandemije, osobito sadržaje izvedbenih umjetnosti. 
U prvom pitanju ispitanici su bili zatraženi da se sjete svojih kulturnih navika prije izbijanja pandemije koronavirusa. Iz odgovora koji su prikazani u tablici 2 vidljivo je da najveći broj ispitanih studenata povremeno ili redovito posjećivao koncerte popularne glazbe $(79,3 \%)$, nešto ih je više od polovice povremeno ili redovito posjećivalo kazališta $(60,1 \%)$ i glazbene festivale $(55,8 \%)$, dok su koncerti klasične glazbe i plesne manifestacije od studenata bili znatno slabije posjećeni.

Tablica 2.

Učestalost sudjelovanja mladih u kulturnim aktivnostima u godini dana prije početka pandemije

\begin{tabular}{|c|c|c|c|c|}
\hline & & Nijednom & $1-3$ puta & 4 puta ili više \\
\hline \multirow{2}{*}{ Kazalište } & $\mathrm{N}$ & 83 & 87 & 38 \\
\hline & $\%$ & $39,9 \%$ & $41,8 \%$ & $18,3 \%$ \\
\hline \multirow{2}{*}{ Koncerte popularne glazbe } & $\mathrm{N}$ & 43 & 122 & 43 \\
\hline & $\%$ & $20,7 \%$ & $58,6 \%$ & $20,7 \%$ \\
\hline \multirow{2}{*}{ Koncerte klasične glazbe } & $\mathrm{N}$ & 169 & 33 & 6 \\
\hline & $\%$ & $81,2 \%$ & $15,9 \%$ & $2,9 \%$ \\
\hline \multirow{2}{*}{ Glazbene festivale } & $\mathrm{N}$ & 92 & 92 & 24 \\
\hline & $\%$ & $44,2 \%$ & $44,2 \%$ & $11,6 \%$ \\
\hline \multirow{2}{*}{ Plesne manifestacije } & $\mathrm{N}$ & 139 & 48 & 21 \\
\hline & $\%$ & $66,9 \%$ & $23 \%$ & $10,1 \%$ \\
\hline
\end{tabular}

Rezultati koji su prikazani u tablici 3, a koji se odnose na učestalost gledanja sadržaja izvedbenih umjetnosti preko ekrana prije pojave koronavirusa, pokazuju da su ispitanici prije pandemije više pratili internetske koncerte nego predstave, i to u najvećoj mjeri na besplatnim platformama kao što je YouTube. Analizirajući odgovore sumarno, najveći je broj studenata barem jednom pogledao snimku koncerta na besplatnim platformama (70\%) ili na televiziji $(58,7 \%)$, predstave na besplatnim platformama pogledalo je ukupno $43 \%$ ispitanika, a na TV-u ukupno $32 \%$ ispitanika. Broj ispitanika koji su prije pandemije plaćali za gledanje internetskih snimki, bilo koncerata bilo predstava, vrlo je mali $(6-7 \%)$. 
Tablica 3.

Učestalost gledanja internetskih sadržaja izvedbene umjetnosti prije početka pandemije

\begin{tabular}{|c|c|c|c|c|}
\hline & & Nikad & $\begin{array}{l}1-3 \text { puta } \\
\text { godišnje }\end{array}$ & $\begin{array}{l}4 \text { ili više puta } \\
\text { godišnje }\end{array}$ \\
\hline \multirow{2}{*}{ Izravan prijenos ili snimke koncerata na TV-u } & $\mathrm{N}$ & 86 & 92 & 30 \\
\hline & $\%$ & $41,3 \%$ & $44,3 \%$ & $14,4 \%$ \\
\hline \multirow{2}{*}{$\begin{array}{l}\text { Izravan prijenos ili snimke koncerata na } \\
\text { besplatnim platformama (Youtube, Facebook i sl.) }\end{array}$} & $\mathrm{N}$ & 61 & 73 & 74 \\
\hline & $\%$ & $29,3 \%$ & $35,1 \%$ & $35,63 \%$ \\
\hline \multirow{2}{*}{ Izravan prijenos ili snimke koncerata uz plaćanje } & $\mathrm{N}$ & 193 & 13 & 2 \\
\hline & $\%$ & $92,8 \%$ & $6,3 \%$ & $0,9 \%$ \\
\hline \multirow{2}{*}{ Izravan prijenos ili snimke predstava na TV-u } & $\mathrm{N}$ & 141 & 54 & 13 \\
\hline & $\%$ & $67,8 \%$ & $26 \%$ & $6,2 \%$ \\
\hline \multirow{2}{*}{$\begin{array}{l}\text { Izravan prijenos ili snimke predstava na } \\
\text { besplatnim platformama (YouTube, Facebook i sl.) }\end{array}$} & $\mathrm{N}$ & 118 & 67 & 23 \\
\hline & $\%$ & $56,7 \%$ & $32,2 \%$ & $11,1 \%$ \\
\hline \multirow{2}{*}{$\begin{array}{l}\text { Izravan prijenos ili snimke predstava } \\
\text { uz plaćanje }\end{array}$} & $\mathrm{N}$ & 195 & 12 & 1 \\
\hline & $\%$ & $93,8 \%$ & $5,8 \%$ & $0,4 \%$ \\
\hline
\end{tabular}

U sljedećem pitanju ispitanici su bili zatraženi da usporede učestalost konzumiranja određenih kulturnih sadržaja prije izbijanja i tijekom razdoblja pandemije. Iz rezultata prikazanih u tablici 4 vidljivo je da se kod studentske populacije tijekom pandemije najviše povećala aktivnost gledanja filmova (55,8\%). Više od polovice ispitanika zadržalo je istu razinu konzumacije kulturnih sadržaja kao i u razdoblju prije pandemije koji se odnose na slušanje glazbe $(60,1 \%)$ i čitanje knjiga $(61,1 \%)$. S druge strane, najviše je opalo posjećivanje izložbi $(63,9 \%)$ i kazališta $(56,3 \%)$, što je i razumljivo s obzirom na zatvaranje kulturnih institucija i zabranu javnih okupljanja. No, činjenica da je 50\% studenata gledalo koncerte u jednakoj mjeri kao i prije pandemije ukazuje na to da su neki alternativni i virtualni načini glazbenih izvedbi ipak doprli do svoje publike. 
Tablica 4.

Konzumiranje kulturnih sadržaja tijekom pandemije

\begin{tabular}{|c|c|c|c|c|}
\hline & & $\begin{array}{c}\text { Manje nego prije } \\
\text { pandemije }\end{array}$ & $\begin{array}{l}\text { Jednako kao i prije } \\
\text { pandemije }\end{array}$ & $\begin{array}{l}\text { Više nego prije } \\
\text { pandemije }\end{array}$ \\
\hline \multirow{2}{*}{ Slušanje glazbe } & $\mathrm{N}$ & 20 & 125 & 63 \\
\hline & $\%$ & $9,6 \%$ & $60,1 \%$ & $30,3 \%$ \\
\hline \multirow{2}{*}{ Čitanje knjiga } & $\mathrm{N}$ & 20 & 127 & 61 \\
\hline & $\%$ & $9,6 \%$ & $61,1 \%$ & $29,3 \%$ \\
\hline \multirow{2}{*}{ Gledanje koncerata } & $\mathrm{N}$ & 80 & 104 & 24 \\
\hline & $\%$ & $38,5 \%$ & $50 \%$ & $11,5 \%$ \\
\hline \multirow{2}{*}{ Gledanje kazališnih predstava } & $\mathrm{N}$ & 117 & 86 & 5 \\
\hline & $\%$ & $56,3 \%$ & $41,3 \%$ & $2,4 \%$ \\
\hline \multirow{2}{*}{ Gledanje filmova } & $\mathrm{N}$ & 21 & 71 & 116 \\
\hline & $\%$ & $10,1 \%$ & $34,1 \%$ & $55,8 \%$ \\
\hline \multirow{2}{*}{ Posjećivanje izložbi } & $\mathrm{N}$ & 133 & 72 & 3 \\
\hline & $\%$ & $63,9 \%$ & $34,6 \%$ & $1,5 \%$ \\
\hline
\end{tabular}

Vezano uz prethodno pitanje, studenti su bili zamoljeni da procijene na skali od 1 do 5 koliko je umjetnost općenito bila važna za njih tijekom razdoblja pandemije, te je gotovo 60\% studenata procijenilo je da im je umjetnost u tom razdoblju bila važna ili vrlo važna, kao što je vidljivo na slici 1 .

Slika 1.

Procjena studenta o tome koliko je umjetnost bila važna za njih tijekom razdoblja pandemije

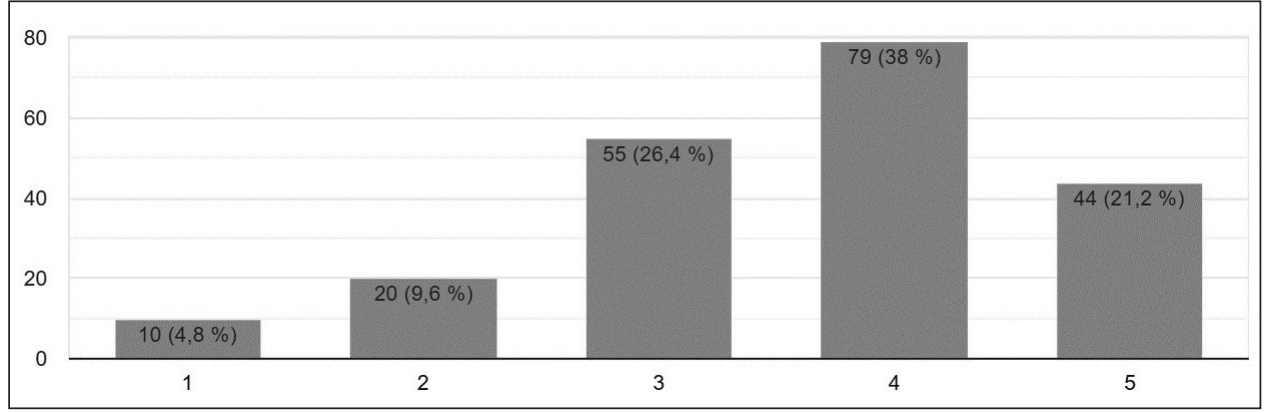


Što se tiče navika praćenja sadržaja izvedbenih umjetnosti na ekranima tijekom razdoblja pandemije, rezultati prikazani u tablici 5 otkrivaju da je više od polovice studenata barem jednom od pojave koronavirusa pogledalo koncert na internetu (58\%), no onih koji su, kako smo ustanovili, veliku ponudu takvih koncerata redovito pratili je manje (tek 15\% snimke internetskih koncerata pogledalo je četiri ili više puta u godini dana). Također, kazališne predstave ili brojne neformalne snimke koje su izvedbeni umjetnici stavili publici na raspolaganje barem je jednom pogledalo oko $40 \%$ studenata, no mali je broj studenata to činio redovito. Stoga ne iznenađuje da studenti uglavnom nisu bili zainteresirani za plaćanje takvog sadržaja. Gledanje internetskih sadržaje platilo je samo $8 \%$ studenata.

Tablica 5.

Učestalost konzumiranja internetskih sadržaja izvedbenih umjetnosti od ožujka 2020. do ožujka 2021. godine

\begin{tabular}{|c|c|c|c|c|}
\hline & & Nijednom & $1-3$ puta & 4 ili više puta \\
\hline \multirow{2}{*}{$\begin{array}{l}\text { Snimke profesionalnih izvedbi koncerata na } \\
\text { besplatnim platformama }\end{array}$} & $\mathrm{N}$ & 87 & 89 & 32 \\
\hline & $\%$ & $41,8 \%$ & $42,8 \%$ & $15,4 \%$ \\
\hline \multirow{2}{*}{$\begin{array}{l}\text { Snimke profesionalnih izvedbi predstava na } \\
\text { besplatnim platformama }\end{array}$} & $\mathrm{N}$ & 127 & 71 & 10 \\
\hline & $\%$ & $61,1 \%$ & $34,1 \%$ & $4,8 \%$ \\
\hline \multirow{2}{*}{$\begin{array}{l}\text { Neformalne snimke glazbenih ili kazališnih } \\
\text { umjetnika (npr. od doma ili probe) }\end{array}$} & $\mathrm{N}$ & 123 & 66 & 19 \\
\hline & $\%$ & $59,1 \%$ & $31,7 \%$ & $9,1 \%$ \\
\hline \multirow{2}{*}{ Snimke koncerata uz plaćanje } & $\mathrm{N}$ & 190 & 18 & 0 \\
\hline & $\%$ & $91,3 \%$ & $8,7 \%$ & 0 \\
\hline \multirow{2}{*}{ Snimke predstava uz plaćanje } & $\mathrm{N}$ & 191 & 17 & 0 \\
\hline & $\%$ & $91,8 \%$ & $8,2 \%$ & 0 \\
\hline
\end{tabular}

Isto je potvrđeno i sljedećim pitanjem, u kojem je od studenata traženo da navedu koliko su prosječno plaćali za gledanje snimki koncerata ili predstava, pri čemu je čak polovica studenata ustvrdila da su gledali samo besplatne sadržaje, 33,7\% ih nije gledalo snimke izvedbi umjetnosti, a manjina koja je plaćala za gledanje uglavnom je plaćala do 100 kuna, što je vidljivo u tablici 6. 
Tablica 6.

Prosječno plaćanje internetskih izvedbi

\begin{tabular}{|l|c|c|}
\hline \multicolumn{3}{|c|}{ Koliko ste prosječno plaćali za gledanje snimki koncerata ili predstava (iznos po izvedbi)? } \\
\hline Iznos u kunama & N & $\%$ \\
\hline $1-50$ kuna & 11 & $5,3 \%$ \\
\hline $51-100$ kuna & 16 & $7,7 \%$ \\
\hline $101-200$ kuna & 5 & $2,4 \%$ \\
\hline 200 kuna ili više & 3 & $1,4 \%$ \\
\hline Gledao sam samo besplatne sadržaje & 103 & $49,5 \%$ \\
\hline Nisam gledao/la ništa od navedenog & 70 & $33,7 \%$ \\
\hline
\end{tabular}

Studenti su snimke izvedbi pratili najčešće na svojim pametnim telefonima $(51,4 \%)$, osobnim računalima $(47,1 \%)$ te na TV-u $(32,2 \%)$.

U otvorenom pitanju studenti su zatraženi da navedu neke od snimki koncerata ili predstava koje su gledali ili za koje su čuli da su bili dostupne putem interneta tijekom pandemije koronavirusa. Prikupljeno je 79 odgovora, koji navode čak stotinjak različitih svjetskih i domaćih kazališnih i glazbenih izvedbi različitih vrsta i žanrova, što pokazuje da su snimke distribuirane preko mreže ipak pronašle put do ciljane publike. Studenti su za internetske nastupe saznali najčešće na društvenim mrežama $(76 \%)$ te nešto manje putem preporuka prijatelja ili obitelji $(28,4 \%)$, iz TV i radio reklama (24\%), putem internetskih bannera (18,8\%) i vijesti (13\%).

Iz rezultata prikazanih na slici 2, koji se odnose na procjenu povratka izvedbama uživo nakon završetka pandemije, vidljivo je da se više od polovice studenata izjasnilo da bi se odmah po završetku pandemije vratili ranijim navikama odlazaka na koncerte i predstave uživo. U nastavku upitnika ispitanici su trebali procijeniti na skali od 1 do 5 kolika je vjerojatnost da će pratiti internetske snimke koncerata i predstava u budućnosti, nakon što pandemija popusti i kada bude moguće ići na izvedbe uživo. Vidljivo je da vrlo mali broj studenata procjenjuje izglednim ili vrlo izglednim da će pratiti internetske snimke koncerata u budućnosti (ukupno 17\%). 
Tablica 7.

Povratak ranijim navikama odlaska na koncerte i predstave uživo

\begin{tabular}{|c|c|c|}
\hline \multirow{2}{*}{ Odmah bih išao/la u jednakoj mjeri kao i prije pandemije } & $\mathrm{N}$ & 123 \\
\hline & $\%$ & $59,1 \%$ \\
\hline \multirow{2}{*}{$\begin{array}{l}\text { Bio/la bih na oprezu i pričekao/la nekoliko mjeseci prije nego bih } \\
\text { ponovno počeo/la ići na koncerte i predstave }\end{array}$} & $\mathrm{N}$ & 66 \\
\hline & $\%$ & $31,7 \%$ \\
\hline \multirow{2}{*}{$\begin{array}{l}\text { Ne bih još duže vrijeme (više od } 6 \text { mjeseci) posjećivao/la koncerte i } \\
\text { predstave zbog straha od zaraze }\end{array}$} & $\mathrm{N}$ & 17 \\
\hline & $\%$ & $8,2 \%$ \\
\hline \multirow{2}{*}{$\begin{array}{l}\text { Mislim da više nikada neću moći posjećivati koncerte i predstave u } \\
\text { uvjetima kao prije pandemije zbog straha od zaraze }\end{array}$} & $\mathrm{N}$ & 2 \\
\hline & $\%$ & $1 \%$ \\
\hline
\end{tabular}

Slika 2.

Praćenje internetskih snimki koncerata i predstava u budućnosti

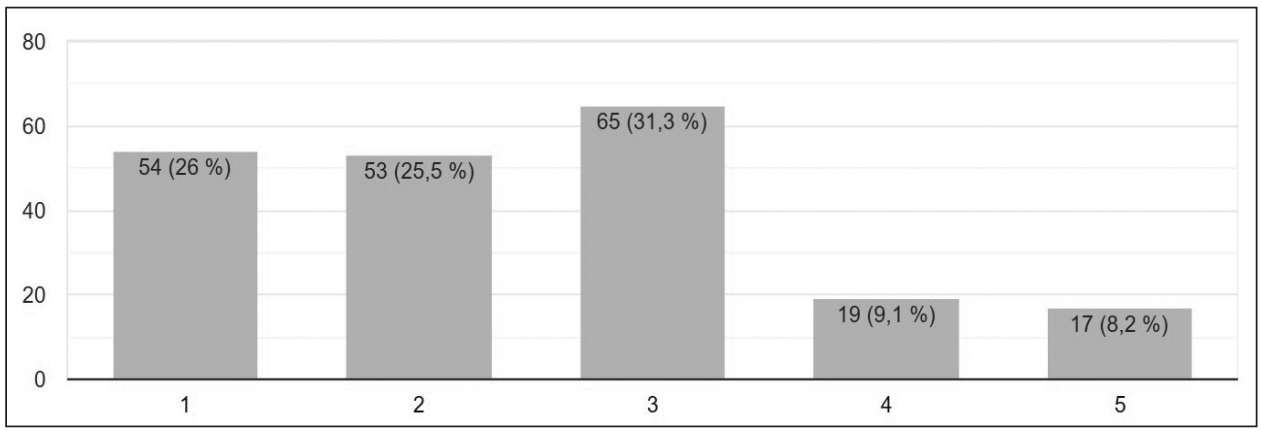

Odgovori na sljedeće pitanje, vezano uz percepcije o internetskim izvedbama, u kojem su ispitanici na Likertovoj skali procjenjivali slaganje s određenim tvrdnjama vezanima uz gledanje nastupa na ekranima, pokazuju da većina studenata (čak 76\%) smatra da internetske izvedbe ne mogu nadomjestiti iskustvo gledanja predstave ili koncerta uživo. Pri praćenju takvih izvedbi tehnologija im uglavnom ne stvara probleme. Ispitanici su odgovorili kako im praćenje internetskih izvedbi nije otežano zbog čestih tehnoloških problema uzrokovanih neadekvatnim kompjutorom ili internetskom vezom $(45 \%)$ ili što se ne bi znali koristiti tehnologijom koja je potrebna za praćenje internetskih izvedbi (94\%), već im kod takvih izvedbi nedostaje interakcija između publike i izvođača (72\%) kao i interakcija s ostalom publikom (66\%). 
S obzirom na ranije navedeno, očekivano je da je manji broj studenata spreman platiti direktno ili indirektno (kroz dobrovoljni prilog ili kupnju CD-a ili suvenira) za pristup internetskoj izvedbi svog omiljenog glazbenika ili pristup internetskoj predstavi. Čak $40 \%$ studenata pristalo bi gledati reklame tijekom izvedbe kako bi sadržaj ostao besplatan, dok ih je $23 \%$ zainteresirano isključivo za besplatne sadržaje bez reklama.

Da internetsku izvedbu ne vrednuju jednako kao izvedbu uživo, pokazuje činjenica da čak $87,5 \%$ ispitanika smatra kako internetska izvedba treba koštati manje od izvedbe uživo. Na pitanje o spremnosti na plaćanje za gledanje internetske izvedbe svog omiljenog glazbenika ili gledanje predstave koja ih zanima studenti odgovaraju da bi platili do 50 kuna (29, 3\%) ili do 100 kuna (29,3\%), dok 22\% ispitanika ne bi platilo ništa, kao što je vidljivo na slici 3.

Slika 3.

Plaćanje maksimalne cijene po jednoj internetskoj izvedbi koncerta ili kazališne predstave

Koliko biste maksimalno platili za gledanje online izvedbe svog omiljenog glazbenika ili predstave koja vas zanima? (iznos po izvedbi)

208 odgovora
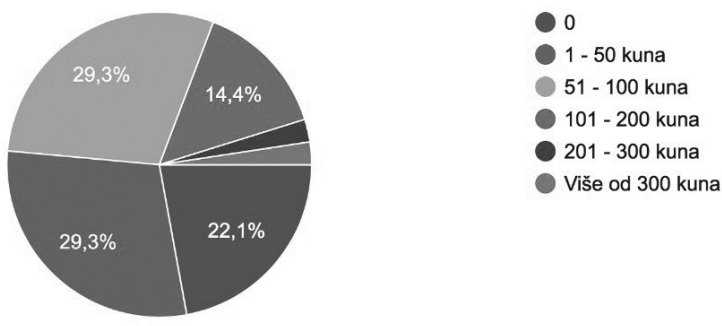

Od eventualnih sadržaja koji bi potaknuli ispitanike da plate ili plate više za internetsku izvedbu, najviše je studenata navelo „pogled iza scene“ (ukupno 55\%) koji bi uključivao osobniju interakciju s umjetnicima kroz snimke proba, ture po studiju, upoznavanje članova tima i slično. Osim toga, na plaćanje bi neke od njih potaknuli i specifično kreirani virtualni doživljaji koji koriste suvremenu digitalnu tehnologiju (54\%), uključivanje publike uživo, poput odgovaranja na komentare publike, mogućnost naručivanja pjesama i tome slično $(51 \%)$ te pogled u svakodnevni život umjetnika (48\%). Ipak, čak polovicu studenata ništa od navedenog ne bi potaknulo na plaćanje internetskih izvedbi.

To je potvrđeno i završnim otvorenim pitanjem, u kojem su ispitanici zamoljeni da napišu postoji li nešto drugo što bi ih potaklo da plate za internetsku izvedbu koncerta ili predstave. Zabilježen je 61 odgovor, od kojih se u većini navodili da ništa ne može zamijeniti koncerte i predstave uživo. Troje studenata odgovorilo je da bi platili za internetsku izvedbu jedino kad bi bila humanitarnog karaktera. 


\section{Zaključak}

U Hrvatskoj postoje brojne institucije, profesionalna i amaterska društva koji djeluju u području izvedbenih umjetnosti i čija reputacija i preživljavanje uvelike ovise o publici, odnosno konzumentima kulturnih sadržaja. Ono što sve izvedbene discipline imaju zajedničko odnos je s publikom o kojemu ovise, zbog čega su im trenutna kriza i ograničenja dale izazov da na što inovativniji i kreativniji način taj odnos održe i na nov način razviju. Većina kulturnih institucija odlučila je iskoristiti prednosti društvenih mreža i ostalih internetskih platformi te svoj sadržaj preseliti u virtualno okruženje. Internetski način izvođenja bio je prisutan i prije pandemije, međutim u znatno manjoj količini te o takvom načinu prenošenja sadržaja kulturne institucije nisu ovisile. Međutim, danas je situacija u potpunosti drugačija. Kulturne institucije doživljavaju ogromne novčane gubitke te je njihova budućnost neizvjesna, a nezavisni umjetnici još su u gorem položaju, zbog čega nastoje na što više načina iskoristiti virtualni svijet i tijekom krize opstati bar na mreži kada već ne mogu na pozornici. Također, ono u što smo se uvjerili tijekom vremena samoizolacije jest važnost kulture, umjetnika i sadržaja koji stvaraju jer je rijetko tko samoizolacijski period proveo bez konzumacije ikakvog kulturnog sadržaja u svoja četiri zida.

Istraživanje provedeno za potrebe ovog rada bilo je eksplorativnog karaktera, a cilj mu je bio korištenjem mješovitih metoda dobiti uvid u raznolika digitalna rješenja koja je ponudio sektor izvedbenih umjetnosti u Hrvatskoj kako bi tijekom razdoblja pandemijske krize ostao u kontaktu sa svojom publikom. Također, željeli smo istražiti stavove i percepcije jednog dijela publike o takvim sadržajima: koliko su ih bili svjesni, u kojoj mjeri i na koji su ih način konzumirali te kakva je budućnost izvedbenih umjetnosti na internetu.

Rezultati provedenog istraživanja pokazuju da su hrvatska kulturne institucije i nezavisni umjetnici vrlo brzo reagirali i odgovorili na pandemijsku krizu pružanjem raznolikog internetskog sadržaja u svim oblicima koji postoje i na globalnoj razini (prijenos uživo, virtualno događanje, snimka na zahtjev). Također, pojavili su se i pokušaji kreativnog istraživanja mogućnosti interneta kao nove umjetničke i kulturne platforme, od kojih smo istaknuli virtualnu predstavu Višnjik u Višnjiku redatelja Bobe Jelčića, koja se izvodila u formi konferencijskog razgovora na platformi Zoom.

Provedena anketa pokazala da je više od polovice ispitanih studenata konzumiralo neke od ponuđenih internetskih sadržaja izvedbenih umjetnosti tijekom razdoblja pandemije, no većina ih je gledala samo besplatne sadržaje. Također, čak 76\% studenata smatra da su internetske izvedbe lošija zamjena za izvedbe uživo i ne iskazuju namjeru praćenja tih sadržaja u većoj mjeri nakon završetka pandemije. Kod internetskih izvedbi u najvećoj im mjeri nedostaje interakcija između publike i izvođača, kao i interakcija s ostalim članovima publike, te se više od polovice studenata $(59,1 \%)$ namjerava vratiti starim navikama odlazaka na koncerte i predstave uživo čim to situacija 
dopusti. Ne čudi stoga da čak $87,5 \%$ studenata smatra da internetske izvedbe trebaju koštati manje nego izvedbe uživo. Premda nije moguće poopćiti dobivene rezultate istraživanja s uzorka na čitavu populaciju, oni su indikativni i ukazuju na trendove koji će utjecati na daljnji razvoj mrežnih oblika distribucije sadržaja izvedbenih umjetnosti tijekom i nakon prestanka pandemije.

\section{Literatura}

3. Banks, M. and O'Connor, J. (2020). "A plague upon your howling": art and culture in the viral emergency. Cultural Trends.

4. Bonin-Rodriguez, P. and Vakharia, N. (2020.) Arts Entrepreneurship Internationally and in the Age of COVID-19. Artivate, 9 (1): 3-7. https://www. jstor.org/stable/10.34053/artivate.9.1.0003\#metadata info tab contents. (Pregledano 23. travnja 2021.)

5. Comunian, R. and England, L. (2020). Creative and cultural work without filters: COVID-19 and exposed precarity in the creative economy. Cultural Trends, 29 (2): 112-128. https://www.tandfonline.com/doi/full/10.1080/0954 8963.2020.1770577. (Pregledano 23. travnja 2020.)

6. Dümcke, C. (2021): Five months under COVID-19 in the cultural sector: a German perspective. Cultural Trends, 30 (1): 19-27.

7. EY (2021.) Obnova Europe: Kulturno i kreativno gospodarstvo prije i nakon COVID-19. https://www.hgk.hr/documents/sazetak-obnova-europe-kulturno-ikreativno-gospodarstvo-prije-i-nakon-covid-19601052c33a873.pdf. (Pregledano 23. travnja 2020.)

8. Florida, R. and Semen, M. (2020). Lost art: Measuring COVID-19's devastating impact on America's creative economy. New York: The Brookings Institution. https://www.brookings.edu/wp-content/uploads/2020/08/20200810 Brookingsmetro_Covid19-and-creative-economy Final.pdf. (Pregledano 23. travnja 2021.)

9. Krolo, K.; Tonković, Ž.; Vidović, D.; Žuvela, A. (2020). Utjecaj pandemije COVID-19 i zagrebačkog potresa na OCD-e u suvremenoj kulturi i umjetnosti. Zagreb: Biblioteka 'Kultura nova'. https://kul- turanova.hr/istrazivanje covid potres/izvjestaj/. (Pregledano 23.travnja 2021. godine)

10. Lee, D.; Baker, W. and Haywood, N. (2020). Coronavirus, the cultural catalyst. Australian Journal of Teacher Education, 43 (5): 16-31.

11. Matarasso, F. (1997). Use or ornament? The social impact of participation in the arts. Stroud: Comedia.

12. Merli, P. (2002). Evaluating the Social Impact of Participation in Arts Activities. International Journal of Cultural Policy, (8) 1: 107-118.

13. Moffat, K. (2020). Digital Engagement with Culture: Exploring the Act Two Survey. Digital The Audience Agency, UK. https://www.theaudienceagency.org/asset/2347. (Pregledano 15. ožujka 2021.) 
14. OECD (2020). Culture shock: COVID-19 and the cultural and creative sectors. http://www.oecd.org/coronavirus/policy-responses/culture-shock-covid-19-andthe-cultural-and-creative-sectors-08da9e0el. (Pregledano 23.travnja 2021.)

15. Polivtseva, E. (2020). Performing arts in times of the pandemic: status quo and the way forward. IETM REPORT. https://www.ietm.org/en/publications/performing-arts-in-times-of-the-pandemic-status-quo-and-the-way-forward. (Pregledano 15. ožujka 2021.)

16. Primorac, J. (2021). Izgubljeni prihodi i pronađena solidarnost: utjecaj prvog vala pandemije bolesti COVID-19 na kulturni sektor u jugoistočnoj Europi. Sociologija i prostor, 59 (219): 219-240.

17. Radermecker, A. (2020.) Art and culture in the COVID-19 era: for a consumeroriented approach. SN Business \& Economics, 1 (4): 1-14. https://link.springer. com/article/10.1007/s43546-020-00003-y. (Pregledano 2. veljače 2020.)

18. Setiawan A. Y.; Bulan, I. and Habsdary, D. (2020.) Social Media as a Platform of Performing Arts Education During COVID-19 Pandemic. ICOPE 2020, Lampung.

19. Sgourev, S. V. (2020). The Pandemic as a Factor of Transformation in Arts and Culture. Artsmanagement.net. https://www.artsmanagement.net/Articles/ThePandemic-as-a-Factor-of-Transformation-in-Arts-and-Culture-The-Ascendance-of-Digital-Culture,4174. (Pregledano 20. veljače 2021.)

20. UNESCO (2020). Culture in Crisis. Policy Guide for a Resiliant Sector. Paris: UNESCO. https://en.unesco.org/creativity/publications/culture-crisis-policyguide-resilient-creative. (Pregledano 23. travnja 2021.)

21. Warnecke, L. (2020) Art and performance during the time of COVID-19 lockdown. Agenda, 34 (3): 145-147.

22. Warren, S. (2020) Good Vibes Friday: Reflections on Livestreaming During the Lockdown. Association for Elecronic Music. https://associationforelectronicmusic. org/2020/11/27/good-vibes-friday-reflections-on-livestreaming-during-thecovid-19-lockdown/. (Pregledano 21. veljače 2021.) 


\title{
Online Performing Arts in the Age of Pandemic: A Necessary Evil or a New Cultural Practice?
}

\author{
Lana Domšić \\ University of Applied Sciences Baltazar Zaprešić, Croatia \\ e-mail: ldomsic@bak.hr \\ Barbara Franić \\ University of Applied Sciences Baltazar Zaprešić, Croatia \\ e-mail:bfranic@bak.hr \\ Lucija Marjanović \\ University of Applied Sciences Baltazar Zaprešić, Croatia \\ e-mail:marjanoviclucija3@gmail.com
}

\begin{abstract}
The current crisis caused by the COVID-19 virus and the consequent measures of restricting gatherings, long-term postponement of public performances and the closure of cultural institutions strongly influenced the performing arts sector. Concerts, theatre and dance imply the gathering of a large number of people and the possibility of collective enjoyment in works of art. The restrictions that still exist have therefore led to major economic losses, job losses and endangerment of existence of independent artists.
\end{abstract}

At the same time, digital media made it possible to offer different cultural content online and various unconventional ways of dance and theatre performances, virtual concerts and special musical events emerged. The online cultural offer was initially free and over time some charging models were introduced.

The aim of this paper was to map different practices of virtual distribution of performing arts in Croatia that emerged in response to the crisis caused by COVID-19 and to explore users' attitudes about online presentation of performing arts and their willingness to pay for such content. The conducted research showed that Croatian cultural institutions and independent artists quickly responded to the pandemic crisis by providing a variety of online content. According to the survey, more than a half of students consumed some of these content during the pandemic period, but the vast majority consider online performances to be a poor substitute for live performances and do not express intent to follow such content after the pandemic.

Key words: cultural and creative sector, performing arts, online performances, digital consumption, COVID-19, pandemic, user research, willingness to pay. 